\title{
Vg2-elevers kontakt med spansk i fritiden: «Det er morsommere å se serier når du skjønner litt spansk»
}

Berit Grønn

Høgskolen i Østfold

berit.gronn@hiof.no

Ane Christiansen

Charlottenlund videregående skole

christiansenane@gmail.com

\section{Sammendrag}

Artikkelen presenterer funn og analyse av siste del av en tredelt undersøkelse om spanskelevers kontakt med spansk språk og spanskspråklig kultur i fritiden. Undersøkelsen ble gjennomført i tidsrommet 2015-18. Den siste delen fant sted skoleåret 2017-18 og bestod av kvalitative intervjuer av 24 elever som hadde spansk nivå II som fellesfag. Målet var å finne konkrete eksempler på hvordan spanskelever i en norsk skolekontekst går fram for å komme i kontakt med spansk utenom klasserommet. Med utgangspunkt i et sosiokulturelt perspektiv på læring, rettes oppmerksomheten spesielt mot hvordan den $\varnothing \mathrm{kte}$ digitaliseringen av samfunnet har betydning for $\mathrm{i}$ hvilke situasjoner og kontekster elevene møter spansk og hvilke spanskspråklige kilder de har tilgang til og benytter seg av.

Intervjuene ble gjennomført i to omganger med fem måneders mellomrom. Resultatene fra første intervjurunde viste at elevene i stor grad, men ofte mer tilfeldig, er i kontakt med spansk i digitale omgivelser, og stort sett gjennom musikk, filmer og tv-serier produsert i USA. Vi fant også at de bevisst utnytter sine forkunnskaper i engelsk i møte med autentisk spansk. I andre intervjurunde utdypet elevene hvordan den angloamerikanske populærkulturen ofte fungerer som en døråpner for kontakt med spansk og spanskspråklig kultur.

Funnene våre viser at digitale verktøy, engelsk språk og kulturuttrykk fra USA synes å være viktige medierende redskaper for elevenes egen språkutvikling og eget spanskspråklig kulturkonsum.

Nøkkelord: spansk, nivå II, fellesfag, digitale verktøy, uformelle læringskontekster 


\section{Innledning}

Når, hvor og hvordan er dagens spanskelever i kontakt med spansk?

På hvilke måter opplever dagens spanskelever spanskfaget som relevant i egen hverdagskontekst? $\mathrm{Og}$, hvordan utnytter de sine erfaringer med spansk utenom skolekonteksten for å komme videre $\mathrm{i}$ egen læringsprosess?

Den digitale utviklingen har åpnet for tilgang til nye kommunikasjonskontekster og nye kommunikasjonsverktøy, og dermed nye og utvidede muligheter for å tilegne seg språk- og kulturkunnskaper. Dette innebærer at dagens elever har større muligheter, både i og utenom skolekonteksten, til å ta personlige valg når det gjelder å oppsøke kilder og situasjoner som gir dem språklig input og utfordringer (Antón 2013: 23; Walker \& White 2013: 9-10).

Som didaktikere i spansk har vi en generell interesse for hva slags diskursive miljøer dagens spanskelever har tilgang til, i og utenom skolekonkteksten, og hvordan kontakt med spansk språk og spanskspråklig kultur i hverdag og fritid kan bidra til å styrke deres spanskkompetanse og utvide deres kulturforståelse. I denne artikkelen vil vi presentere resultatene fra tredje og siste fase i en eksplorerende unders $\varnothing$ kelse blant spanskelever i videregående skole. Hele unders $\emptyset$ kelsen, som er en kombinasjon av kvantitative og kvalitative metoder, ble gjennomført i perioden 2015-18 (Grønn, kommende; Christiansen \& Grønn 2017). Det overordnede temaet for undersøkelsen var i hvilke sammenhenger spanskelever er i kontakt med spansk utenom skolekonteksten, både i fysiske møter og i digitale omgivelser. Hovedmålet var å finne ut mer om hvilke muligheter elevene har til å praktisere språket, hvordan de benytter seg av disse og hvordan de utnytter dem i egen språklæring (Christiansen \& Grønn 2017: 3-4). Vi ønsket å avdekke noen sentrale tendenser og få mer konkret informasjon om i hvilke sammenhenger dagens spanskelever møter spansk, og hva slags erfaringer de gjør seg når de bruker språket. Deretter ville vi gå i dybden på enkelte områder som informantene brakte på banen (ibid.: 6).

\section{Forankring i laereplanen}

Spansk har siden innføringen av Kunnskapsløftet i 2006 (heretter LK06), vært det mest valgte fremmedspråket i norsk skole, både på ungdomstrinnet (Doetjes 2018: 31) og i den videregående opplæringen (Utdanningsdirektoratet 2015: 54; Fremmedspråksenteret 2019: 1-2). Ifølge gjeldende Laereplan i fremmedspråk (Utdanningsdirektoratet 2006: 2) gir læring av et nytt 


\section{Nordic Journal of Modern Language Methodology}

fremmedspråk oss mulighet til å komme i kontakt med andre mennesker og kulturer, noe som igjen kan gi økt forståelse for hvordan mennesker lever og tenker. Videre vektlegges det at elevene skal få anledning til å bygge videre på tidligere språklæringserfaringer, utvikle sine kommunikative språkferdigheter (å lese, lytte, snakke og skrive) og lære seg språk i et flerspråklig perspektiv. Et overordnet mål er å ruste elevene til å ta målspråket i bruk i forskjellige sammenhenger (Speitz 2018: 41). Dette er også et uttalt mål i den nye læreplanen i fremmedspråk (Utdanningsdirektoratet 2019), som innføres fra og med 01.08.2020. Der fremheves det blant annet at viktige kompetanseområder i en globalisert verden er å kunne kommunisere på flere språk og å tilegne seg kunnskap om andre kulturer og levesett. En slik kompetanse utvikler elevene gjennom så vel formell som uformell kommunikasjon (ibid.: 2).

Ett av kompetansemålene på nivå II i gjeldende Lareplan i fremmedspråk (heretter lareplanen) er at eleven skal kunne «vurdere og utnytte kommunikasjonsteknologi til samarbeid og møte med autentisk språk» (Utdanningsdirektoratet 2006: 5). I forbindelse med fagfornyelsen (LK20) er Språk og teknologi kommet inn som et eget kjerneelement i fremmedspråkfaget, og det presiseres følgende: «Å utforske og utnytte faglig relevant språkteknologi og nye medier gir utvidede muligheter for kreativ og kritisk læring» (Utdanningsdirektoratet 2019: 2).

I dagen samfunn er den digitale teknologien en naturlig og integrert del av hverdagslivet og utdanningssystemet. Elevenes språklæringsprosess må derfor sees i sammenheng med deres bruk av teknologi (Walker \& White 2013: 2; 9). Spansk og engelsk er blant de fem mest talte språkene i verden, og på Internett er engelsk det mest brukte språket etterfulgt av spansk på tredjeplass (Instituto Cervantes 2018: 5). I et nasjonalt og globalt perspektiv har engelsk en dominerende rolle, som skolefag og som lingua franca (Rindal 2014: 8). Samtidig vinner spansk terreng på flere områder. I dag snakkes eksempelvis spansk av 50 millioner i USA, og dette tallet er stigende, slik at USA sammen med Mexico i 2060 vil være de to landene med flest spansktalende i verden (Instituto Cervantes 2018: 1).

\section{En unders $\phi$ kelse inndelt $i$ tre faser}

Antall informanter i unders $\varnothing$ kelsen var totalt 246. Utvalget av informanter i de tre fasene, hvor lenge de hadde lært spansk og på hvilket nivå de befant seg på i den formelle opplæringen på intervjutidspunktet (jf. studieforberedende utdanningsprogram i 
LK06 og lareplanen) er forskjellig. Den geografiske spredningen i datamaterialet varierer også. ${ }^{1}$

Det empiriske materialet bygger på elevenes egenrapportering om konkrete situasjoner og kontekster der de praktiserte spansk. ${ }^{2}$ Den tredje fasen, som denne artikkelen omhandler, fant sted skoleåret 2017-18 og bestod av en kvalitativ intervjuundersøkelse. 24 elever som hadde spansk nivå II som fellesfag i Vg2 deltok. I utarbeidelsen av undersøkelsen tok vi utgangspunkt i noen av hovedfunnene i de to foregående fasene.

I den første fasen (2015-2016), der Vg3-elever med spansk som programfag deltok, fant vi at de i varierende, men utstrakt grad hadde tilgang til spansk i hverdag og fritid. En tredjedel av elevene benyttet digitale verktøy bevisst for å få tilgang til spansk i fritiden, hovedsakelig for å lytte til musikk, finne informasjon om temaer som interesserte dem (sport, mote) i digitale medier som nettaviser, blogger og videoblogger. Elevene poengterte at de ofte støtte på spansk tilfeldig på Internett og i massemedia, og at dette ga dem gode muligheter til å trekke veksler på sine engelskog spanskkunnskaper (Christiansen \& Grønn 2017: 12).

Funnene fra den andre fasen (2017-18), der elever ved norske videregående skoler i Spania deltok, viste mange av de samme hovedtendensene. Selv om disse elevene i utgangspunktet hadde lettere tilgang til spansk i nærmiljøet, varierte det veldig i hvor stor grad de praktiserte spansk. De fleste understrekte at fordelen med å bo i Spania var vel så mye at de befant seg i et internasjonalt miljø, fikk praktisert engelsk og ble åpne og tolerante for en rekke språk og kulturer (Grønn, kommende).

I undersøkelsens siste fase (2017-18) rettet vi fokus mot et utvalg spanskelever som representerte et stort antall elever i videregående opplæring: Mens det årlig er cirka 700 elever som velger programfaget spansk nivå III i Vg3, er det i gjennomsnitt 30000 elever som har spansk nivå II som fellesfag (Utdanningsdirektoratet 2018). I denne siste runden ønsket vi å få tak

\footnotetext{
${ }^{1}$ I den første fasen (2015-16) deltok totalt 205 Vg3-elever som hadde valgt programfaget spansk nivå III og som befant seg i en norsk hverdags- og skolekontekst. Denne delstudien besto av en elektronisk kartleggingsunders $\emptyset$ kelse som ble sendt ut til skoler over hele Norge. 181 elever besvarte undersøkelsen. Deretter, basert på funnene i kartleggingsunders $\varnothing$ kelsen, fulgte vi opp med en kvalitativ intervjuunders $\varnothing$ kelse, der 24 elever fordelt på fire fylker og fire byer, deriblant to mindre byer, én stor og Oslo, deltok.

I undersøkelsens andre fase (2016-17) gjorde vi kvalitative intervjuer blant spanskelever i vg2 og vg3 ved to norske videregående skoler i Spania. 17 elever deltok totalt. Disse fordelte seg på følgende nivåer: Nivå I (1), Nivå II (10), Nivå I-II (3) og Nivå III (2). Målet var å undersøke hvordan disse elevene utnyttet mulighetene til å praktisere spansk i fritiden, spesielt med tanke på muntlig interaksjon, og om det var noen signifikante forskjeller mellom hvordan spanskelever ved videregående skoler i Norge og Spania praktiserte spansk i fritiden (Grønn, kommende).
} 


\section{Nordic Journal of Modern Language Methodology}

i konkrete eksempler på hvordan elevenes kontakt med spansk språk og spanskspråklig kultur når de befinner seg her i Norge, arter seg. Vi stilte derfor følgende forskningsspørsmål:

- Hvordan går elevene fram for å få tilgang til spansk språk og spanskspråklig kultur i fritiden?

- Hvor målrettet er denne kontakten? Oppsøker de språket og kulturen bevisst eller dukker den bare opp rundt dem?

- Hva slags spanskspråklige kilder oppsøker elevene, og hva slags refleksjoner gjør de seg om disse kildene?

Vi vil først presentere teoriene vi støtter oss på og datainnhentingsmetoden vi brukte. Deretter legger vi fram resultatene fra undersøkelsen og diskuterer dem. Resultatene er for begrensede til å kunne gi fullstendig bilde av hvordan spanskelever i videregående skole kommer i kontakt med spansk i fritiden. De kan imidlertid gi noen konkrete eksempler og indikasjoner på hvordan denne kontakten arter seg. Resultatene og diskusjonen vil derfor først og fremst bidra til å etablere ny kunnskap om hvilke broer som etableres mellom formell og uformell læring i spansk, og med det gi et diskusjonsgrunnlag for videre forskning.

\section{Teoretisk ramme}

I et sosiokulturelt perspektiv formes mennesket og dets tenkning av sosiale og kulturelle omstendigheter. Læring skjer gjennom deltakelse i sosiale praksiser, både på makronivå, eksempelvis innen institusjoner som familie og skole, og på mikronivå, eksempelvis gjennom sosialt samspill og relasjoner med familie og venner (Lantolf \& Poehner 2014: 12).

Læringskontekster kan følgelig være formelle eller uformelle, og det individet tar opp i seg (appropierer) i den ene, kan iverksettes i den andre, og vice versa.

Menneskets fysiske, intellektuelle og sosiale evner avgjøres ikke bare av dets naturlige forutsetninger, men også av at det er i stand til å utvikle og bruke redskaper for å mediere handlingene sine gjennom bruk av redskaper eller artefakter. Disse kan være semiotiske (språk, tegn, ideer) eller instrumentelle (fysiske). I sosial interaksjon med andre mennesker og med kulturelle verktøy fanger individet opp språklige modeller og det kulturelle forrådet som er blitt utviklet gjennom historien. Mediasjoner er således innfelt i en historisk ramme, og den historiske utviklingen påvirker hvordan vi handler og tenker, hva vi lærer og hvordan (Bråten 2002: 23; 
Säljö 2016: 108). Endringer i de sosiale og kulturelle omgivelsene, som teknologiske nyvinninger, medfører dermed endrede betingelser for språklæringen (Lantolf \& Poehner 2014: 40).

Gilje (2017: 20-21) fremhever at det sosiokulturelle perspektivet egner seg godt for å vise fram sammenhengen mellom menneskelig tenkning og de digitale redskapene. Artefakter som verktøy kan være funksjonelle, det vil si at de kan brukes for å finne relevante kilder og tekster om verden, og semantiske, det vil si at de er representasjoner av kunnskap om verden. Våre kunnskaper om verden finnes imidlertid ikke i selve objektene og hendelsene, men i våre diskurser om disse og i artefaktene (Säljö 2001: 240).

Vygotsky (1978: 57) regner kulturelle og kognitive redskaper som språk og skriving, og kognitive prosesser som logisk hukommelse, selektiv oppmerksomhet og begrepsdanning som betydningsfulle i danningen av høyere psykologiske prosesser. Ved hjelp av psykologiske redskaper kan mennesket styre sin oppmerksomhet og organisere sin beslutningsprosess (Bråten 2002: 27). Videre skiller Vygotsky mellom spontane begreper, som vi tilegner oss gjennom hverdagslige aktiviteter, og vitenskapelige begreper, som vi tilegner oss i formelle opplæringskontekster (Vygotskij 2001: 171). Begge former for læring driver den språklige tenkningen på et høyere plan. Dette medfører at fremmedspråklæring kan være en målstyrt og bevisst aktivitet, eller spontan og tilfeldig (Lantolf \& Thorne 2011: 207).

Oxford og Schramm (2007: 52) trekker paralleller mellom Vygotskys teorier om høyere psykologiske prosesser og det vi i dag vil kalle 'strategier'. Vygotskys ideer om menneskets evne til å analysere og sammenfatte vil kunne falle inn under det vi i dag kaller kognitive strategier. Likeledes kan hans ideer om menneskets evne til å planlegge, overvåke og evaluere egen læring kategoriseres som metakognitive strategier (ibid.).

Læringsstrategier kan være fagovergripende, eller knyttet til spesifikke fag: Oxford (2017: 48) gir følgende definisjon av språklæringsstrategier: «... complex, dynamic, thoughts and actions, selected and used by learners with some degree of consciousness in specific contexts in order to regulate multiple aspects of themselves (such as cognitive, emotional, and social)». Hun understreker at læringsstrategier oppstår og eksisterer på et mentalt/intellektuelt plan, men kan også manifestere seg i fysiske handlinger, og dermed observeres. Hun fremhever også betydningen av konteksten når man skal unders $\emptyset$ ke valg og bruk av språklæringsstrategier. Hvilke strategier språkinnlærere velger, vil således avhenge av både personlige og kontekstuelle faktorer, 


\section{Nordic Journal of Modern Language Methodology}

eksempelvis individuelle læringspreferanser, hvem man kommuniserer med og setting (tid, sted) (Oxford 2017: 2; 48).

Walker og White (2013: 9) argumenter for at den digitale teknologien må sees i sammenheng med konteksten den inngår i, og det aktivitetssystemet som den medierer: Den digitale teknologien er ikke bare en støtte for språklæringen, men en integrert del av en helhetlig kontekst, der språk eksisterer og tas i bruk. Tidligere generasjoners innsikter og menneskers felles erfaringer bygges i økende grad inn i teknikken (Säljö 2016: 176). I det 21. århundre utgjør for eksempel Internett en gedigen kunnskapsbase, og der er oppstått nye former for kommunikasjon, for eksempel nettsteder der brukerne selv bidrar og skaper innholdet (som YouTube og Instagram). Dette skaper nye former for mellommenneskelige relasjoner. Alle disse digitale kommunikasjonsformene og kildene kan fungere som læringsressurser for språkinnlærere (Walker \& White 2013: 14-18; Gee \& Hayes 2011: 35).

\section{Metode}

For å besvare forskningsspørsmålene valgte vi kvalitative intervjuer som datainnsamlingsmetode, og la opp til semistrukturerte fokusgruppeintervjuer. Vi intervjuet til sammen 24 elever som hadde spansk nivå II ved tre videregående skoler. I forkant av intervjuene tok vi kontakt med tre spansklærere ved tre ulike skoler via e-post, der vi forklarte hva undersøkelsen gikk ut på og at vi var på jakt etter intervjuobjekter som hadde spansk nivå II som fellesfag. Vi kjente litt til lærerne fra før, men hadde ikke samarbeidet med dem tidligere om undervisning i deres spanskklasser. De tre lærerne stilte seg positive til at intervjuene ble gjennomført blant deres spanskelever. Vi ba skolens ledelse om tillatelse til å gjennomføre intervjuene og laget et kort informasjonsskriv om undersøkelsens tema og hvordan intervjuene skulle foregå. Dette ble delt ut til alle elevene i de tre spanskklassene, som hver bestod av mellom 20-30 elever. Elevene bestemte selv om de ville delta eller ikke, og vi endte opp med sju fra den ene skolen, sju fra den andre og ti fra den tredje. De tre skolene lå i større byer og fordelte seg på to fylker (Trøndelag og Oslo). Intervjuobjektene bestod altså av en relativt homogen gruppe. Intervjuene foregikk i to runder. Det første intervjuet fant sted i fysiske møter på elevenes respektive skoler i oktober 2017. Oppfølgingsintervjuet, med de samme intervjuobjektene, ble gjennomført på samme vis i mars 2018. Hvert intervju varte i cirka 45 minutter. Antall deltakere i hvert av intervjuene varierte mellom tre til fem elever i begge intervjurundene. 


\section{Nordic Journal of Modern Language Methodology}

Samtale gir innblikk i informantenes livsverden, og det skjer gjerne gjennom fortellinger og historier. Ifølge Swain, Kinnear og Steinman (2015: xii) er personlige fortellinger et godt verktøy for å få bedre kjennskap til språkinnlærerens erfaringer med og forestillinger om målspråket. En narrativ tilnærming kan derfor gi forskeren verdifull informasjon om hvordan språkinnlæreren går fram i ulike kontekster, og hvorfor (Oxford 2017: 101-102). I fokusgruppeintervjuer, der deltakerne utgjør en relativt homogen gruppe, skapes det dessuten en gruppedynamikk som gjør at de setter ord på felles erfaringer og reflekterer sammen. Dette gir forskeren mulighet til å identifisere fellestrekk og delte oppfatninger (Patton 2015: 476).

\section{Første intervjurunde}

Til den første intervjurunden utarbeidet vi en intervjuguide med ni åpne spørsmål, der vi ba elevene beskrive i hvilke situasjoner og kontekster de var i kontakt med og brukte spansk i fritiden. Tre av spørsmålene rettet seg spesifikt mot hva de lyttet til og leste på spansk, i hvilken forbindelse og hvorfor. ${ }^{3}$ I fokusgruppene ga vi rom for at elevene kunne dele, utdype og fortelle om sine personlige erfaringer med spansk utenom skolearbeidet. Samtidig kunne de trekke linjer mellom den kontakten de hadde med spansk i fritiden og det de gjorde og lærte i spansktimene på skolen.

Vi gjorde opptak av intervjuene, og transkriberte dem i etterkant. I bearbeidelsen av det empiriske materialet foretok vi en meningsfortetning, men fors $\varnothing \mathrm{kte}$ å ivareta meningsinnholdet. Vi hadde ikke etablert noen tematiske kategorier på forhånd, og utviklet koder og kategorier med bakgrunn i de innhentede dataene, jf. Corbin og Strauss (2015: 7-8). Vi gjennomgikk de narrative dataene i tre runder, gjorde sammenligninger og fors $\emptyset$ kte til slutt å finne noen overordnede temaer som kunne danne utgangspunkt for neste intervjurunde. Vi lagde først en relativt lang liste over enkeltord og fraser som gikk igjen under intervjuene, og koblet noen av dem sammen (ibid.: 220; 236-37). Eksempler på dette er spansk, engelsk, venn/venner, familie, hфre, lytte, følge med, forstå,

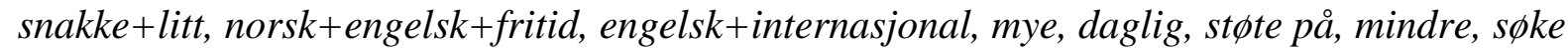
etter, strømming, tv-serier+engelsk+spansk+USA, musikk+engelsk+spansk, latinopop osv.

\footnotetext{
${ }^{3}$ De tre spørsmålene var: 1) Hva gjør du for å lese og lytte til spansk i fritiden? Hva leser og lytter du til? (f.eks. spanskspråklige filmer, tv-serier, musikkvideoer, blogger, nyheter, sanger, bøker, interaktive oppgaver på nett osv.), 2) Har noen anbefalt deg disse tekstene/nettstedene, eller har du funnet fram til dem på egen hånd? 3) Hvorfor leser / lytter du til disse tekstene?
} 


\section{Nordic Journal of Modern Language Methodology}

Deretter reduserte vi antall temaer ved å finne ord og fraser som innholdsmessig og tematisk sett overlappet hverandre (ibid.: 239-41), og endte på totalt 18. Nedenfor følger noen eksempler:

Engelsk fritid, støte på engelsk, engelsk+internasjonalt, mye, bruke til daglig, engelske i filmer/tv-serier; spansk i filmer/tv-serier/musikk på engelsk;

Spansk fritid, venn/venner, familie, støte på spansk, mindre, høre, lytte, forstå, snakke litt, stort i USA, tv-serier fra USA, spansk+internasjonalt snakke fort, konsentrere meg, følge med;

Internett strømmetjenester, Netflix, YouTube, mest engelsk og norsk, engelsk og spansk sammen, forstå, gjette, sammenligne

Basert på kodingen og kategoriseringen vi hadde gjort så langt, kom vi fram til tre overordnede temaer: 1) Kontakt med spansk i fysiske mфter, 2) Kontakt med spansk i digitale kontekster, og 3) Engelsk og grammatikk-kunnskap som medierende verkt $\phi y$.

\section{Andre intervjurunde}

Resultatene fra første intervjurunde viste at informantene hovedsakelig fikk tilgang til spansk språk og spanskspråklig kultur gjennom engelskspråklige kanaler og kilder på nettet, og at disse kildene ofte var knyttet til musikk-, film- og underholdningsbransjen. Vi utarbeidet derfor en ny intervjuguide til runde to, slik at vi kunne gå i dybden på disse temaene. Vi formulerte fire åpne spørsmål, der vi blant annet ba elevene beskrive hvordan de utnyttet forbindelsen mellom spansk og engelsk i egen språklæringsprosess, og hva som var fordelaktig med den måten de nærmet seg den spanskspråklige kulturen på. ${ }^{4}$

Etter å ha gjennomført intervjuene, transkriberte vi dem. Vi fulgte samme prosedyre i bearbeidelsen og analysen av de innhentede dataene som i første intervjurunde. En god del av de samme ordene dukket opp igjen, men det empiriske materialet inneholdt også en rekke andre ord. Dette kom til uttrykk i ord og fraser som eksponert for, morsmål, automatisk/naturlig,

\footnotetext{
${ }^{4}$ De fire spørsmålene i delen Spansk og engelsk var: 1) Fortell hva engelsk og spansk har med hverandre å gjøre. Hva tenker dere på når dere hører ordene «engelsk og spansk» sammen? 2) Kan dere gi eksempler på hvordan engelsk og spansk opptrer sammen i muntlige og skriftlige tekster dere støter på (tv-serier, film, blogger, sangtekster o.l.) 3) Hvordan utnytter dere språkkunnskapene deres i engelsk for å forstå spansk, og vice versa? Kan dere gi noen eksempler? 4) Hvordan åpner kjennskapen dere har til engelskspråklig kultur dørene for å bli bedre kjent med spanskspråklig kultur, og vice versa?
} 


\section{Nordic Journal of Modern Language Methodology}

blanding/miks, kjent/nart, ukjent/annerledes, nordamerikansk+kultur+kjent. I den andre runden, da vi reduserte antall hovedkategorier, kom derfor noen nye momenter og nyanseringer inn. Her følger to eksempler:

Kultur nordamerikansk kultur, latinamerikansk kultur, meksikanere, USA, kontekst, kjent kultur, vår kultur, ukjent kultur, internasjonal

TV-serier Netflix, dialog, skuespillere, dialoger på engelsk, dialoger på spansk, litt engelsk+litt spansk, fin blanding, forstå begge deler

Vi ble stående igjen med to overordnede temaer 1) Bevissthet om egne framgangsmåter i digitale kontekster, og 2) Engelsk som kulturell dфråpner.

Det at de to intervjurundene fant sted med fem måneders mellomrom, gjorde at vi kunne følge de samme elevene i et utviklingsperspektiv når det gjaldt hva som opptok dem mest, i tillegg til at vi kunne innhente mer informasjon om det vi fant i første runde.

Vi ser i etterkant at den geografiske spredningen kunne ha vært bedre. Samtidig var det ingen av elevene som oppga å ha kontakt med spansk språk knyttet spesifikt til stedet de bor. Dersom man skulle ha hatt med geografi som faktor, så måtte undersøkelsen ha hatt et annet og mye større format. For å få et større informasjonsgrunnlag kunne det derimot kanskje ha vært en fordel om vi hadde kombinert den kvalitative metoden med en kvantitativ tilnærming, slik vi la opp til i den første fase av undersøkelsen (Christiansen \& Grønn 2017: 6). På den annen side bidro det at vi konsentrerte oss om få informanter (totalt 24) i to intervjuomganger til at vi kunne oppnå mer detaljert informasjon på individ- og gruppenivå, jf. Corbin og Strauss (2015: 7-8).

Intervjuunders $\varnothing$ kelsen ble meldt inn til Norsk senter for forskningsdata, og elevenes personvern er ivaretatt. Navnene til elevene er anonymisert.

\section{Resultater fra første intervjurunde}

\section{1) Kontakt med spansk i fysiske møter}

Informantene understreker at de omgir seg med og bruker mest norsk og engelsk i fritiden, og noen er ikke i kontakt med spansk i det hele tatt i fysiske møter. Likevel er det forholdsvis mange av informantene som oppgir at de har spansktalende personer i sin omgangskrets, men ingen 


\section{Nordic Journal of Modern Language Methodology}

oppgir å ha nære venner eller familiemedlemmer de primært snakker spansk med. Kontakten de har med spansk i fysiske møter i hverdagen og på fritiden er dermed relativt sporadisk, og går for det meste ut på at de fors $\varnothing$ ker å forstå hva andre sier. Følgende elevsitat er representativt:

Jeg har en venn. Mora hans er fra Chile. De snakker mest norsk hjemme. Han snakker bra spansk, men vi bruker spansk mest for å hilse på hverandre, sier hola, adiós, spør hvordan det går og så videre. Men han forteller mye fra Chile.

\section{2) Kontakt med spansk i digitale kontekster}

Elevene kommer i kontakt med spansk på ulike digitale flater. Noen ganger opps $\varnothing$ ker de spanskspråklige kilder bevisst, men for det meste støter de på spansk tilfeldig, hovedsakelig i engelskspråklige tv-serier og filmer, der enkelte innslag foregår på spansk. Kontakten elevene har med spansk i digitale omgivelser i fritiden går for det meste ut på å forstå, så vel muntlig tale som skrevne tekster.

Gjennom bruk av digitale medier får elevene tilgang til representasjoner av den spansktalende verden. Av auditive og audiovisuelle kilder nevnes sanger på musikkstrømmetjenester og musikkvideoer på YouTube hyppigst. Elevene lytter primært til latino-pop, der artistene fremfører deler av sangen på spansk og engelsk, eller bare på spansk. Fotballinteresserte elever bruker sosiale medier til å oppdatere seg på det siste innen fotballverdenen. En del elever følger spanskspråklige kjendiser på Instagram, og noen har venner på Facebook som skriver på spansk, men elevene legger sjelden ut kommentarer på spansk selv. De som har medelever som tilbringer skoleåret på utveksling i et spansktalende land får input på spansk ved å holde kontakten med dem i sosiale medier, slik som disse fire:

Vi har jo ei venninne som er på utveksling i Argentina nå i Vg2. Hun legger ut litt på norsk, engelsk og spansk i sosiale medier, sånn at alle vennene kan følge med. Vi leser det som står på spansk. Det lærer vi litt av. Hun går på vanlig videregående skole i Argentina og har lært masse. Vi blir inspirert av at hun har lært så mye spansk på kort tid.

Av elevene som bevisst oppsøker spanskspråklige nettsider, oppgir noen at de leser nyheter på spansk og/eller lytter til musikk, men generelt sett er de lite opptatt av å gå i dybden på disse tekstene: 


\section{Nordic Journal of Modern Language Methodology}

Manu Chao, for eksempel, har et politisk budskap. Jeg gjenoppdaget Manu Chao i Vg1. Jeg hadde hørt om han fra før. Jeg forsøker å forstå hva han synger om, jeg tenker på hva jeg tror det kan bety, men jeg slår ikke opp ord og sånn. Men egentlig hører jeg ikke så mye spansk.

\section{3) Engelsk og grammatikk-kunnskaper som medierende verktøy}

Når elevene støter på sanger der det synges delvis på engelsk, delvis på spansk, bruker de ofte engelskkompetansen sin for å danne seg et bilde av hovedtema i sangen, samt gjenkjenne og gjette betydningen av ordene på spansk. I tillegg støtter de seg på visuelle uttrykk i musikkvideoer. I følgende sitat refererer eleven til Luis Fonsi og Justin Bieber sin versjon av Despacito:

Det er litt lettere når sangen starter på engelsk. Da skjønner du at det handler om ei jente og så går det over til spansk etter hvert. Når du har fått med deg introen så er det lettere å tolke resten.

Når de lytter til eller leser spansk i fritiden, bruker de sjelden digitale ordbøker eller oversetterprogram, for målet er ikke å gå i dybden på teksten. Det hender at de tyr de til Ordnett, Clarify, SpanishDict, WordReference og Google Translate, men det gjør de mest på skolen når de trenger informasjon på detaljnivå. De er klar over at man ikke kan stole på Google Translate som hjelpemiddel alene, og oversetter ofte både fra spansk til norsk og fra spansk til engelsk, slik at de kan dobbeltsjekke hva som stemmer overens.

Flesteparten foretrekker engelsk-spanske ordbøker (begge veier) framfor norsk-spanske. Følgende elevuttalelse er representativ: Jeg foretrekker ordbøker i engelsk-spansk. Det fine er at de gir eksempler på hvert ord og på hva det kan bety, i sammenhenger der ordet brukes. Enkelte elever trekker også fram kunnskaper om de grammatiske systemene i spansk som et viktig semiotisk redskap både for å forstå og gjøre seg forstått, og denne kunnskapen tilegner de seg i spanskundervisningen: Vi har behov for å laere grammatikk for å få oversikt og for å vite hva vi kan og hva vi ikke kan. De ordene som ikke ligner, må du bare lare deg å pugge til det sitter, men du klarer liksom å huske på de engelske ordene og da sitter de.

\section{Resultater fra andre intervjurunde}

\section{1) Bevissthet om egne framgangsmåter i digitale kontekster}




\section{Nordic Journal of Modern Language Methodology}

Når det gjelder sang/musikk på spansk, lytter elevene hovedsakelig til artister som også synger på engelsk. Noen av disse er av spansk eller latinamerikansk opprinnelse, men bosatt i USA, eksempelvis Enrique Iglesias og Kat Dahlia, eller artister fra Puerto Rico. Elevene synes det er en stor fordel at samme sang finnes både i spansk og engelsk versjon, eller at noen deler synges på engelsk, andre på spansk. Det gjør det lettere å skjønne hovedinnholdet i sangen.

For å se på tv-serier og filmer i fritiden benytter elevene seg hovedsakelig av strømmetjenester, og underholdningsserier på Netflix er hyppig nevnt. Seriene er stort sett produsert i USA, og elevene trekker frem serier som foregår på en blanding av engelsk og spansk, blant annet Breaking Bad, Narcos, Jane the Virgin, Riverdale, Orange Is the New Black, Dexter, Modern Family, Prision Break og Hannibal. ${ }^{5}$ Handlingen i disse seriene er lagt til USA, med unntak av Narcos, som foregår i Colombia, men der hovedrolleinnhaverne er agenter fra den føderale etaten DEA. Elevene framhever at spansk språk og latinamerikansk kultur er en stor del av kulturen i USA, i tillegg til spanskspråklige land, og at det dermed er naturlig at dette kommer til uttrykk i de nevnte underholdningsseriene: De snakker spansk i nesten alle amerikanske serier. Når det dukker opp dialoger på spansk, skjerper de oppmerksomheten, og gir som eksempel dialoger i serien Jim Hurts, der bestemoren alltid snakker spansk. Et annet eksempel er Riverdale, der det er en spansktalende familie. Ifølge elevene er det en stor fordel at de spanske dialogene kommer innimellom dialoger på engelsk. De understreker også at innslagene på spansk ofte er enkeltord og korte setninger, noe som gjør det lettere å forstå: I seriene er det som regel ganske enkel spansk, sånn som abuelo, vamos og andre korte ord, ikke så mange setninger. Samtidig stiller noen av elevene seg kritisk til hvordan serier som Narcos framstiller USA sitt bidrag til bekjempelsen av narkotikasmugling, og foretrekker spanskspråklige filmer og serier om samme tema. Av andre spanskproduserte serier nevner enkelte at de følger Las chicas del cable.

For å sikre forståelsen støtter noen av elevene seg på norske undertitler fordi spansktalende skuespillerne snakker veldig fort. Det betyr imidlertid ikke at de støtter seg på undertitlene alene, men at de samtidig forsøker å fange opp og forstå replikkene på spansk. Ser de på engelskspråklige serier og filmer med innslag av spansk, forholder de seg som oftest til undertitler på engelsk: [...] er serien på engelsk, har vi kanskje ikke undertitler, men hvis det kommer noe på

\footnotetext{
${ }^{5}$ Dette er underholdningsserier som var populære på intervjutidspunktet (2017-18).
} 
spansk, popper det opp undertitler på engelsk automatisk. Noen få foretrekker også undertitler på spansk, som denne eleven:

Jeg prøver å finne spanske serier og filmer, men igjen, de snakker jo på en måte veldig fort. Så selv om jeg prøver å følge med, så kan det hende jeg har prøvd å se etter serier der det er spansk undertekst istedenfor, for da hører du det du vet fra før, sånn som engelsk, og så ser jeg oversettelsen på spansk og da kan jeg lære mer.

Elevene opplever det som tilfredsstillende å skjønne spansk, både når de ser på spanskspråklige serier og andre serier, der det i utgangspunktet ikke forutsettes at man behersker spansk: Det er morsommere å se serier når du skjфnner litt spansk.

Når elevene utdyper hvordan grammatikk-kunnskapene hjelper dem når de hører spansk i fritiden, trekker de blant annet fram som eksempel verbalperifrasen estar + gerundium, som tilsvarer to be + -ing-formen i engelsk. Under intervjuene diskuterte enkelte av elevene om det var mest hensiktsmessig å søke på / legge inn kun enkeltord eller hele setninger når de brukte digitale ordbøker og oversetterprogram. Et gjentakende argument var å søke på enkeltord, og så sjekke hvordan oversettelsen passet inn i den konkrete konteksten: Vi har jo lart setningsbygginga, så det er bedre å skrive inn søkeord i infinitiv. På nettet ligger mange sangtekster på spansk i oversatt versjon til engelsk, noe elevene mente er en rask og enkel mulighet til å sammenligne ord, og dermed forstå tekstinnholdet. Noen legger inn hele sangtekster i et oversettelsesprogram, men de fleste har bare behov for å søke på enkeltord som de ikke forstår.

Elevene mener at deres forkunnskaper i engelsk er et vel så viktig hjelpemiddel som digitale ordbøker og oversetterprogram når de skal sikre tekstforståelsen. Ifølge elevene er det lettere å koble spanske ord til engelske ord enn norske: Det er jo en liten sammenheng. Det hender jo at når du vet det engelske ordet, så skjønner du på en måte det spanske ordet også. I tillegg til at de bevisst utnytter likheten mellom spansk og engelsk som gjenkjennelsesstrategi, bruker de også denne kunnskapen for å memorere spanske ord og for å planlegge eget læringsarbeid:

Hvis jeg skal prøve å lære meg nye spanske ord, så prøver jeg å se om jeg kan assosiere det med et engelsk ord fordi det kan man ofte, og da er det mye lettere å huske på det.

Advantage og ventaja hører du ligner. Det hjalp meg veldig i alle fall. Det kommer jeg ikke til å glemme. 
Fra elevenes synspunkt er et godt grunnlag i engelsk en avgjørende faktor for å kunne lykkes med spansk, da de kan dra veksler på sine språklæringserfaringer i engelsk for å komme videre i spansk, både i og utenom skolen:

Jeg lærte meg ganske tidlig engelsk ved å se filmer med undertekst og det fikk meg til å lære det veldig godt, så jeg tenker egentlig at hvis jeg gjør det samme på spansk, så kan jeg kanskje ha den samme utviklinga, for det er jo ikke så forskjellig. Det er jo bare et annet språk.

Samtidig mener enkelte at språklæring i fritiden arter seg annerledes på engelsk og spansk, fordi de støter på engelsk mye oftere enn spansk:

Jeg bruker ofte engelsk når jeg skal lære meg spansk. Begge språkene er jo ikke morsmålet vårt, liksom, men i hvert fall engelsk blir vi eksponert for veldig mye. Det er ikke like mye spansk, så det er litt vanskeligere å lære seg det, føler jeg. Det å kunne bruke det til daglig, da.

\section{2) Engelsk som kulturell døråpner}

I den andre intervjurunden forklarte elevene hvordan underholdningsfilmer og -serier som er produsert i USA, fungerer som innfallsport til den spanskspråklige kulturen. I utgangspunktet er det lettere å relatere seg til kulturuttrykk i engelskspråklige serier, fordi det er noe kjent fra før, og når det kommer innslag på spansk i disse seriene, oppleves også disse kulturuttrykkene som nære:

Hvis jeg går inn på Netflix og slår opp på en serie på et språk jeg ikke kjenner, så går jeg ut med en gang. Jeg liker å høre i bakgrunnen litt det kjente - engelsk eller norsk eller noe jeg kan. Jeg vet ikke, men det høres mer interessant ut hvis det er en serie på engelsk enn hvis det er en serie på spansk. Men hvis det kommer spansk inni da så er det liksom helt greit.

Vi er jo vokst opp med den amerikanske kulturen. Hvis det for eksempel er en film om amerikansk high school så vet vi jo hvordan det er der, for vi har jo sett så mange serier om det hele livet, mens vi vet jo ikke hvordan skolekulturen i spansktalende land er, liksom. Det er jo noe helt annet, kan jeg se for meg.

Når elevene velger hvilke tv-serier eller filmer de skal se på i fritiden, faller altså valget som oftest på serier produsert i USA, men at disse seriene er tilpasset et engelskspråklig publikum og ispedd 


\section{Nordic Journal of Modern Language Methodology}

spansk, framstiller de som uproblematisk, og heller som en bonus, særlig med tanke på å forstå hva som blir sagt:

Når de snakker spansk i serier fra USA, så snakker de saktere og tydeligere for da er det liksom beregna på et fremmedspråklig publikum. Da har de jo lagd det for amerikanere, og da vil de jo gjerne tilpasse det, så da blir det ikke så vanskelig spansk.

\section{Diskusjon}

Språklæring kan være en bevisst og målrettet aktivitet, der vi aktivt oppsøker kilder og kommunikasjonskontekster der målspråket brukes, eller noe vi støter tilfeldig på. Også i de tilfeldige situasjonene kan vi skjerpe oppmerksomheten for å forstå hva som blir sagt eller skrevet og/eller anstrenge oss for å ytre oss. Det som først kan virke som tilfeldig språklæring, kan følgelig ta form som en målrettet og meningsfull aktivitet, avhengig av hvordan vi styrer vår vilje og oppmerksomhet (Lantolf \& Thorne 2011: 218).

Funnene våre viser at elevene bevisst oppsøker spansk i fritiden i begrenset grad, men at de engasjerer seg for å forstå når de tilfeldigvis blir eksponert for språket, og det blir de først og fremst i den digitale verden. Selv om elevene ikke oppsøker spansk bevisst eller selv bidrar aktivt med ytringer i sosiale medier og andre nettfora, så retter de oppmerksomheten mot det andre sier og skriver på spansk. Ett eksempel på dette er de fire elevene som bruker sosiale media for å holde kontakten med medeleven som er på utvekslingsopphold i Argentina. Dette gjør at de får tilgang til innlegg på spansk, som de ellers ikke ville hatt tilgang til. Slik bidrar den digitale teknologien til å skape mellommenneskelige kontakt, samtidig som den blir en kilde for autentiske tekster i elevenes språklæring, jf. Walker og White (2013: 9) og Gee og Hayes (2011: 35).

En hovedtendens i resultatene er at elevene foretrekker innslag på spansk i engelskspråklige filmer og tv-serier produsert i USA (hovedsakelig fiksjonstekster innenfor rammen av populærkulturen) framfor produksjoner på kun spansk. De forklarer dette med at disse filmene og seriene ligger dem nærmere kulturelt sett. Elevenes valg av strategier i sin tilnærming til spansk i digitale kontekster har altså en affektiv dimensjon: De går via kanaler som kjennes trygge og som vekker positive følelser. Oxford (2017: 214) påpeker at selv om flere innen fremmedspråksforskningen har begynt å sette søkelyset på sammenhengen mellom språklæringsstrategier og følelsesmessige faktorer, gjenstår fortsatt mye forskning innen dette 
feltet. Ett bidrag i så henseende kan være å undersøke nærmere hva norske elever opplever som kjent/ukjent i spanskspråklige kulturuttrykk.

Man kan tro at det er ugunstig for elevenes språkutvikling i spansk at de i uformelle læringssituasjoner generelt er mye mer i kontakt med engelsk enn spansk. Fra elevenes synspunkt slår dette imidlertid positivt ut: Det er nettopp gjennom de engelskspråklige kildene de får tilgang til spansk. Dette er i tråd med Eide (2013: 4), som mener at en av forklaringene på den økende interessen for spanskfaget i norsk skole i de senere år er USA sin rolle som den fremste kulturleverandøren i Norge. Hun henviser da spesielt til den såkalte latinokulturen som nordmenn har stiftet kjennskap til først og fremst gjennom musikk og mat. Allikevel, sett i lys av at spansk er det tredje mest brukte språket på Internett (Instituto Cervantes 2018: 5), utnytter elevene i relativ liten grad mulighetene til å praktisere spansk i digitale omgivelser. Dette kan nok, slik intervjuobjektene selv kommer inn på, delvis begrunnes med den dominerende posisjonen engelsk har både på skolen og ellers i vår hverdagskontekst, jf. Rindal (2014: 8).

Artefakter som verktøy kan være semantiske (Gilje 2017: 21), og i den forbindelse kan man stille spørsmål om hva innslagene på spansk i engelskspråklige serier produsert i USA, gjør med elevenes forestillinger om spanskspråklige kulturer. I intervjuene viste elevene sine evner til å analysere og sammenfatte (kognitive strategier) da de forklarte hvordan dialogene på spansk i engelskspråklige tv-serier gjenspeiler familiesituasjonen for mange hispanos i dagens USA: Spansk er deres hjemmespråk, og et kommunikasjonsverktøy som ofte brukes i nære relasjoner. Under intervjuene hadde vi imidlertid ikke tid til å gå dypere inn på hvordan elevene vurderte innholdet i disse dialogene, eller måten hispanos blir framstilt på. Etter vårt syn, er dette et tema det absolutt bør forskes videre på, da det er i elevenes diskurser om de semantiske verktøyene man kan avdekke hvordan de skaper mening og tar del i kunnskapen i verden (Lantolf \& Poehner 2014: 48).

Selv om elevene i unders $\varnothing$ kelsen vår oppgir at de forsøker å praktisere spansk når mulighetene byr seg, er det engelsk og norsk de omgir seg med og bruker mest. I de senere år har strømmetjenestene gitt nordmenn økt tilgang til et vidt spekter av filmer, tv-serier og musikk, både på engelsk, spansk og andre språk (IPFI 2018: 9; 14-15; Statistisk sentralbyrå 2018). Dette styres i stor grad av markedskreftene, og er et fenomen som våre intervjuobjekter mener de klarer å utnytte i egen språklæringsprosess, særlig for å trene reseptive ferdigheter. Under intervjuene beskrev elevene detaljert hvordan de går fram for å sikre tekstforståelsen når de møter spansk i 


\section{Nordic Journal of Modern Language Methodology}

digitale kontekster, spesielt hvordan de aktiverer sine forkunnskaper (ordkunnskap i spansk og engelsk; grammatikk-kunnskaper; likheter og forskjeller i grammatiske strukturene i spansk og engelsk). Strategiene de velger er altså gjenstand for bevisste valg, jf. Oxford (2017: 48).

Elevene understreker viktigheten av at de i skolesammenheng får anledning til å utvide sine ord- og grammatikk-kunnskaper, jf. elevuttalelsen om at «vi har behov for grammatikk for å få oversikt». Ordkunnskapen og de lingvistiske forkunnskapene de har i spansk og engelsk er dermed noen av de viktigste semiotiske redskapene elevene anvender, ikke bare for å sikre at de forstår ytringer på spansk, men også i planleggingen og overvåkingen av eget læringsarbeid (metakognitive strategier). Flere av elevene beskriver hvordan de systematisk bruker assosiasjonsstrategier for å memorere nye spanske ord (koble dem med engelske ord).

Flerspråklighet var ikke vårt hovedfokus da vi i 2015 satte i gang vår tredelte unders $\varnothing$ kelse om elevenes kontakt med spansk i fritiden. Ser vi på hvilke temaer elevene selv brakte på banen i løpet av intervjuene (hele undersøkelsen 2015-2018), kan det virke som elevene på spansk nivå III (Vg3) bruker engelsk som læringsstillas i noe mindre grad enn spanskelevene på nivå II (Vg2), men vår undersøkelse er ikke tilstrekkelig til å påvise noen signifikante forskjeller. Det bør derfor forskes videre på hvordan norske spanskelever bruker sin flerspråklighet som ressurs i møte med spansk.

\section{Konklusjon}

I denne siste delen av vår undersøkelse om spanskelevers kontakt med spansk i fritiden (2017-18) framgår det tydelig at engelsk er et viktig hjelpemiddel og en døråpner til spansk, både språklig og kulturelt. I digitale omgivelser får elevene tilgang til spansk særlig gjennom tv-underholdning og musikk, og selv om noen oppgir at de bevisst oppsøker spanskspråklige kilder, oppstår denne kontakten som oftest tilfeldig gjennom mediekonsum i hovedsak i form av produksjoner fra USA. Spanskspråklig kultur produsert i USA er også ofte ment for et fremmedspråklig (engelskspråklig) publikum, og framstår derfor lettere tilgjengelig også for våre elever, både språklig og kulturelt. I fokusgruppeintervjuene reflekterte elevene over egne tilnærminger til spansk gjennom å rekonstruere selvopplevde situasjoner. Samtalene hadde altså også en medierende funksjon. Elevene var bevisste på at de utnyttet sin engelskkompetanse og de språklæringsfaringene de har tilgjengelig i møte med spansk, men nevnte sjelden hvordan de bruker sin norskkompetanse. Vi 


\section{Nordic Journal of Modern Language Methodology}

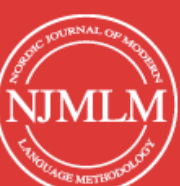

2019, 7 (1), 29-49 Peer reviewed

antar imidlertid at de også nyttiggjør seg denne kompetansen, men det var ikke et tema elevene selv tok opp i vår undersøkelse.

Tradisjonelt sett har elever i fremmedspråkfaget hatt tilgang til språket gjennom tekster læreren har presentert for dem. Takket være den digitale utviklingen finnes det et stort mangfold av spanskspråklige kilder lett tilgjengelig. Vår undersøkelse gir noen indikasjoner på hvordan et større kildeutvalg i digitale medier utnyttes av spanskelever i fritiden. Dette materialet kan brukes i spanskklasserommet for å bevisstgjøre elevene, og danne utgangspunkt for å gi dem en mer allsidig og bred tekstkompetanse.

Når elevene selv i stadig større grad blir i stand til å finne fram til spanskspråklig kultur selv, så er det kanskje enda viktigere at man i skolefaget spansk legger til rette for å jobbe med fagkunnskap og strategier de kan benytte seg av både i formelle og uformelle kontekster. Dette vil hjelpe dem til å vurdere kvaliteten på tekster de leser eller lytter til, for eksempel på Internett, jf. Hopfenbeck (2014: 29). Til slutt, og ikke minst, er det viktig å lære dem opp i de grunnleggende ferdighetene de trenger for også å kunne utvide sitt spanskspråklige kulturkonsum på en enda mer nyansert og konstruktiv måte. Alt dette er delkompetanser som det allerede jobbes systematisk med i skolen, og som er vektlagt både i den overordnede delen av læreplanen (Utdanningsdirektoratet 2017) og i den nye læreplanen i fremmedspråk (LK20).

\section{Litteratur}

Antón, M. (2010). Aportaciones de la teoría sociocultural al estudio de la adquisición del español como segunda lengua. Revista española de lingüística aplicada, Vol. 23, 9-30.

Bråten, I. (red.) (2002). Vygotsky i pedagogikken. Oslo: Cappelen Akademisk forlag.

Christiansen, A. \& Grønn, B. (2017). Spansk nivå III - nye læringsmuligheter og deltakelse i læringsrom i hverdag og fritid. Nordic Journal of Modern Language Methodology, 5 (1), 315. http://journal.uia.no/index.php/NJMLM/article/view/383/370\#.XG6wx-hKg2w

Corbin, J. \& Strauss, A. (2015). Basics of qualitative research. Techniques and procedures for developing grounded theory (4. utg.). Thousand Oaks: Sage.

Doetjes, G. (2018). Fransk, spansk og tysk i ungdomsskolen etter Kunnskapsløftet: styrket eller ikke? Nordic Journal of Modern Language Methodology, 6 (2), 28-56. Hentet 15.11.18. fra https://journal.uia.no/index.php/NJMLM/article/view/513/432\#.Xc5VRldKiUk

Eide, L. (2013). Forestillinger om spanskfaget: et kritisk blikk på lærebøker i spansk. Acta Didactica. Vol.7 Nr.1. Art 4. DOI: http://dx.doi.org/10.5617/adno.1111

Fremmedspråksenteret (2019). Elevens valg av fremmedspråk på videregående skole 2018-19. Nasjonalt senter for engelsk og fremmedspråk i opplæringen. Notat 2/2019. Hentet 21.11.19. fra 


\section{Nordic Journal of Modern Language Methodology}

2019, 7 (1), 29-49 Peer reviewed

https://www.fremmedspraksenteret.no/neted/services/file/?hash=57cbee29ebf51c7ca9cc523 $\underline{79 \mathrm{c} 247 \mathrm{~b} 80}$

Gee, J.P. \& Hayes, E.R. (2011). Language and Learning in the Digital Age. Oxon/New York: Routledge.

Gilje, Ø. (2017). Laremidler og arbeidsformer i den digitale skolen. Bergen: Fagbokforlaget.

Hopfenbeck, T. (2014). Strategier for laring. Om selvregulering, vurdering og god undervisning. Oslo: Universitetsforlaget.

Instituto Cervantes (2018). El español: una lengua viva. Informe 2018. Hentet 12.11.19. fra https://cvc.cervantes.es/lengua/anuario/anuario_18/informes_ic/p05.htm

IPFI [International Federation of the Phonographic Industry] (2018). Global Music Report 2018. Hentet 27.02.18. fra https://www.dropbox.com/s/1ar88aen70yl1c0/GMR2018.pdf?dl=0

Lantolf, J.P. \& Thorne, S.L. (2011). Sociocultural Theory and Second Language Learning Development. I: VanPatten, B. \& Williams, J. (red.). Theories in Second Language Acquisition, 207-226. New York: Routledge.

Lantolf, J.P. \& Poehner, M.E. (2014). Sociocultural Theory and the Pedagogical Imperative in L2 Education: Vygotskian Praxis and the Research/Practice Divide. London: Routledge.

Oxford, R.L. (2017). Teaching and Researching Language Learning Strategies. Self-Regulation in Context. New York: Routledge.

Oxford, R.L. \& Schramm, K. (2007). Bridging the gap between psychological and sociocultural perspectives on L2 learning strategies. I: Cohen, A.D. \& Macaro, E. (red.). Language Learner Strategies: Thirty Years of Research and Practice, 47-68. Oxford: Oxford University Press.

Patton, M.Q. (2015). Qualitative Research \& Evaluation Methods. Los Angeles: SAGE Publications.

Rindal, U. (2014). What is English? Acta Didactica. Vol.8 Nr.2. Art 4. DOI: https://doi.org/10.5617/adno.1137

Speitz, H. (2018). Nasjonale læreplaner og internasjonale perspektiver. I: Bjørke C., Dypedahl, M. \& Haukås, Å. (red.). Fremmedspråksdidaktikk, 33-48. Oslo: Cappelen Damm Akademisk.

Statistisk sentralbyrå (2018). Markant $\varnothing$ kning i bruk av strømmetjenester. Hentet 27.02.18. fra https://www.ssb.no/kultur-og-fritid/artikler-og publikasjoner/markant-okning-i-bruk-avstrommetjenester

Swain, M., Kinnear P. \& L. Steinman (2015). Sociocultural Theory in Second Language Education: An Introduction through Narratives. Bristol: Multilingual Matters.

Säljö, R. (2001). Laering i praksis. Et sosiokulturelt perspektiv. Oslo: Cappelen Damm Akademisk.

Säljö, R. (2016). Laring. En introduksjon til perspektiver og metaforer. Oslo: Cappelen Damm Akademisk.

Utdanningsdirektoratet (2006). Lareplan i fremmedspråk. Hentet 21.11.19. fra https://www.udir.no/k106/FSP1-01

Utdanningsdirektoratet. (2015). Utdanningsspeilet. Hentet fra https://www.udir.no/globalassets/filer/tall-og forskning/rapporter/utdanningsspeilet_2015.pdf

Utdanningsdirektoratet (2017). Overordnet del -verdier og prinsipper for grunnopplaringen. Hentet 30.12.19. fra

https://www.udir.no/lk20/overordnet-del/ 


\section{Nordic Journal of Modern Language Methodology}

Utdanningsdirektoratet (2018). Fagvalg i videregående skole - elever. Fremmedspråk. Fellesfag. Spansk II og I+II. Hentet 27.02.19. fra https://www.udir.no/tall-ogforskning/statistikk/statistikk videregaende-skole/fagvalg-i videregaende-skole/fagvalg-vgs/

Utdanningsdirektoratet (2019). Laereplan i fremmedspråk. Hentet 21.11.19. fra https://www.udir.no/lk20/fsp01-02

Vygotsky, L.S. (1978). Mind in Society: the Development of Higher Psychological Processes. Boston: Harvard University Press.

Vygotskij, L.S. (2001). Tenkning og tale. Oslo: Gyldendal Akademisk.

Walker, A. \& White, G. (2013). Technology Enhanced Language Learning. Connecting theory and practice. Oxford: Oxford University Press. 